Jurnal Konstruksi Hukum | ISSN: 2746-5055

Vol. 2, No. 1, Januari 2021 Hal. 72-75 | Tersedia online di https://www.ejournal.warmadewa.ac.id/index.php/jukonhum

DOI: https://10.22225/jkh.2.1.2971.72-75

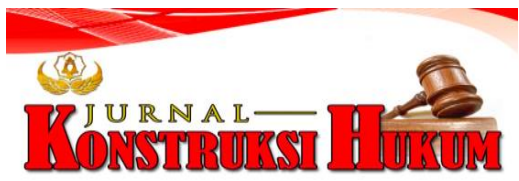

\title{
PERLINDUNGAN HUKUM BAGI PEKERJA UD. ALAM DI BANJAR PENDEM KABUPATEN JEMBRANA
}

\author{
I Komang Angga Triyadi Giri, I Nyoman Putu Budiartha, Luh Putu Suryani \\ Fakultas Hukum, Universitas Warmadewa, Denpasar-Bali, Indonesia
}

\begin{abstract}
Abstrak
Setiap pekerjaan memiliki resiko masing-masing tidak terkecuali tenang kerja UD. Alam. Penelitian ini bertujuan untuk mengetahui bentuk perlindungan hukum UD. Alam di dalam melaksanakan jaminan kecelakaan kerjanya. Jenis penelitiannya menggunakan hukum empiris. Hasil penelitian menunjukan bahwa bentuk perlindungan hukum tanggung jawab UD. Alam yang telah diberikan terhadap pekerjanya berupa perlindungan ekonomis dimana pekerjanya diberikan upah minimum kabupaten/kota (UMK), perlindungan teknis dimana pekerjanya diberikan waktu penyesuaian terhadap alat- alat yang dipergunakan di perusahaan yang belum biasa digunakan, dan perlindungan sosial dimana pihak UD. Alam membiayai pengobatan dan memberikan santunan berupa uang tunai, apabila ada salah satu karyawannya yang mengalami kecelakaan kerja. Sampai saat ini UD. Alam belum mendaftarkan pekerjanya kedalam program jaminan kecelakaan kerja sehingga Pelaksanaan program jaminan kecelakaan kerja di UD. Alam Banjar Pendem Kabupaten Jembrana belum terlaksana secara efektif. Kemudian, faktor ekonomi menjadi kendala UD. Alam belum mendaftarkan pekerjanya kedalam program jaminan kecelakaan kerja, hal ini disebabkan oleh beratnya beban yang ditanggung pengusaha untuk membayar iuran jaminan kecelakaan kerja dan juga prosedur untuk pengajuan jaminan kecelakaan kerja selalu terhambat dengan syarat- syarat yang tidak lengkap sehingga membutuhkan waktu terlalu lama untuk mendaftarkan pekerjanya kedalam program jaminan kecelakaan kerja.
\end{abstract}

Kata kunci: Perlindungan Hukum, Tenaga Kerja, Jaminan Kecelakaan Kerja.

\begin{abstract}
Every job has its own risk, including the quiet work of UD. Natural. This study aims to determine the form of legal protection of UD. Nature in carrying out his work accident insurance. This type of research uses empirical law. The results showed that the form of legal protection is the responsibility of UD. Nature that has been given to workers in the form of economic protection where workers are given a district / city minimum wage (UMK), technical protection where workers are given time to adjust to the tools used in companies that are not yet commonly used, and social protection where the UD. Nature pays for medical treatment and provides compensation in the form of cash, if one of her employees has a work accident. Until now, UD. Alam has not registered his workers in the work accident insurance program so that the work accident insurance program at UD. Alam Banjar Pendem Jembrana Regency has not been implemented effectively. Then, economic factors become an obstacle to UD. Alam has not registered its workers into the work accident insurance program, this is due to the heavy burden borne by employers to pay work accident insurance contributions and also the procedures for applying for work accident insurance are always hampered by incomplete requirements so it takes too long to register workers into the work accident insurance program.
\end{abstract}

Keywords: Legal Protection, Labor, Work Accident Insurance

\section{PENDAHULUAN}

Indonesia berpatokan pada negara-negara yang dalam kurun waktu beberapa tahun saja dari negara berkembang menjadi negara maju. Strategi saat ini berfokus pada pembangunan dan pengembangan negara melalui bidang ekonomi sampai industri kemudian bersama masyarakat menjadikan negara Indonesia menjadi negara maju. Strategi tersebut tidak dapat dilakukan sendiri namun bersama dengan masyarakat dengan kesadaran mau bergerak membangun negeri. Kreatifitas penduduk dalam membuat serta memasarkan produk sampai keluar negeri merupakan salah satu poin penting dan segala tindak usaha dan perbuatan masyarakat harus sesuai dengan peraturan yang berlaku serta hukum yang ada saat sekarang (Husni, 2016).

Menjadi warga negara kreatif harus pandai - pandai melihat peluang tanpa memikirkan rasa takut gagal dalam berusaha. Pemerintah bersama strategi membangun Indonesia maju senantiasa memberi 
lapangan pekerjaan seluas - luasnya bagi mereka yang mau bersama - sama membangun negeri. Memanfaatkan teknologi informasi salah satu cara memperkenalkan suatu produk namun jangan sampai informasi yang sudah disebar menjadi bumerang bagi produk sendiri semisal seseorang memberitahukan bahan baku produk makanan yang dipasarkan membuat salah seorang pihak lain memproduksi makanan sama namun dengan harga yang lebih murah membuat informasi menjadi pisau bermata dua karena memberitahukan hal positif tetapi menjadi negatif karena terdapat produk kualitas sama tetapi harga lebih murah. Sebagai tenaga kerja pembangunan negara merupakan pekerjaan mulia karena pembangunan negara menjadi pemicu datangnya minat warga negara lain berkunjung ke Indonesia. Sebagai tenaga kerja yang baik harus menggunakan alat pelindung diri guna menghindari hal yang tidak diharapkan. Menjaga pola hidup sehat agar terhindar dari penyakit yang membuat berkurang waktu kerja dikarenakan diharuskan beristirahat (Asyhadie, 2008).

Sebagai tenaga kerja memiliki peran penting dalam pembangunan negeri, tanpa ada tenaga kerja Indonesia bisa dikatakan peringkat pertama negara yang memiliki hutang terbanyak (Wijayanti, 2009). Setiap perusahaan yang menggunakan tenaga kerja diwajibkan memperhatikan kesejahteraan tenaga kerja dengan mendaftarkan tanggungan kesehatan sampai tanggungan keluarganya. Tujuannya membuat tenaga kerja menjadi leluasa menjalankan pekerjaannya.

Dalam upaya meminimalisir kecelakaan dalam bekerja dan demi menjaga diri tenaga kerja agar tidak mengalami luka, sakit bahkan hal tidak diinginkan maka tenaga kerja diwajibkan menggunakan alat pelindung diri saat bekerja, dengan menggunakan alat pelindung diri yang menunjang keselamatan kerja juga menjadikan tempat kerja menjadi bersih, aman dan kondusif apa bila ada pelanggan yang berkunjung untuk sekedar melihat - lihat atau membeli produk yang di buat para tenaga kerja. Semakin hari perkembangan dunia industri sangat meningkat memicu terjadinya banyak produksi dan keadaan rawat penyakit yang disebabkan dari alat kerja maupun dari tenaga kerja sendiri maka bagi pekerja agar selalu peduli lingkungan tempat bekerja, menjaga diri dari kontak dengan benda yang memiliki kuman agar semua kegiatan mulai dari produsi sampai pencatatan dapat terlaksana dengan baik.

UD. Alam merupakan perusahaan yang terletak di Banjar Pendem Kabupaten Jembrana bergerak di bidang produksi kayu khususnya pembuatan mebel dan alat-alat rumah tangga yang terbuat dari bahan dasar kayu. Di dalam praktek kegiatan produksinya, UD. Alam selalu menggunakan alat-alat yang berbahaya seperti alat pemotong kayu berjenis senso, gergaji, dan alat-alat sejenis lainnya yang bersifat tajam. Di dalam penggunaan alat-alat tersebut berdasarkan informasi yang didapat dari salah satu pekerja, bahwa keselamatan pada saat menggunakan alat-alat tersebut sering kali terjadi kecelakaan kerja yang ditimbulkan karena kelalaian pekerja sendiri maupun kesalahan teknis dari alat-alat tersebut.

\section{METODE PENELITIAN}

Pencarian informasi secara normatif berpatokan pada peraturan pemerintah yang berfokus pada anak sebagai objeknya dan analisis dalam Informasi yang didapat secara konseptual (Soekanto \& Mamudji, 2003). Penelitian hukum normatif adalah hukum kepustakaan yang mengacu pada norma hukum yang terdapat dalam peraturan Perundang-undangan (Waluyo, 2002) (Marzuki, 2011). Pendekatan perundangan - undangan adalah melakukan suatu penelitian dengan berpatokan pada undang undang sebagai dasar penulisan. Pendekatan kasus dilakukan guna melihat, mencatat dan memahami permasalahan yang diangkat dalam skripsi ini dengan tidak keluar dari zona hukum positif. Penulis meneliti kasus ini menggunakan metode normatif dan kualitatis dimana dalam pengerjaannya penulis menelaah isu hukum dengan didasari peraturan - peraturan hukum Perbankan di Indonesia (Ahmad, 2008).

\section{HASIL DAN PEMBAHASAN}

Perusahaan Alam merupakan pengrajin alat - alat rumah tangga yang sudah memiliki nama dan terkenal dengan kualitas barang yang dihasilkan kualitas baik, berbagai produk seperti peralatan rumah tangga, meja, kursi dan produk lain yang menunjang kemewahan sebuah ruangan dapat di buat di UD. Alam, ditambah para tenaga kerja sudah berpengalaman selama bertahun tahun memproduksi produk yang sudah di pesan sampai ke luar negeri membuat perusahaan ini memiliki penghasilan tetap serta tenaga kerja yang sejahtera dikarenakan banyak orederan yang masuk. Berdiri sejak tahun 2010 sampai saat sekarang selalu dibanjiri pesanan barang selain produk yang sudah banyak 
dipasarkan perusahaan ini dapat membuat produk sesuai pesanan pelanggan seperti produk yang menunjang kegiatan dapur, kantor dan rumah. Tenaga kerja yang kompeten dibidangnya akan membuat para pelanggan tidak akan kecewa dengan hasil yang di buat di perusahaan UD. Alam.

Suksesnya tenaga kerja menghasilkan produk yang bernilai saing tinggi tentu tidak lepas dari fasilitas yang didapatkan, pembuatan produk lebih mudah dan cepat karena mesin yang dipergunakan selalu terawat dengan baik jika terjadi kerusakan maka akan ada teknisi yang siap memperbaiki tanpa memakan waktu sampai berhari - hari. Segala sesuatu yang didapat diperusahaan UD. Alam semua berstandar nasional sesuai dengan pasal 86 tentang ketenagakerjaan yang berisi para tenaga kerja mendapatkan hak mereka sebagai berikut:

1. Alat keselamatan kerja yang menunjang produksi sebuah produk.

2. Tenaga kerja yang memiliki tangggung jawab terhadap pekerjaannya.

3. Mendapatkan fasilitas dan komisi yang sesuai dengan anggaran perusahaan yaitu standar daerah serta tunjangan diluar gaji.

Kecelakaan kerja termasuk penyakit akibat kerja merupakan risiko yang harus dihadapi oleh tenaga kerja dalam melakukan pekerjaannya. Untuk menanggulangi hilangnya sebagian atau seluruh penghasilan yang diakibatkan oleh adanya risiko-risiko sosial seperti kematian atau cacat karena kecelakaan kerja baik fisik maupun mental, maka diperlukan adanya jaminan kecelakaan kerja. Dalam upaya peningkatan perlindungan pekerja ini pemerintah telah memberikan perlindungan berupa jaminan sosial tenaga kerja yang diselenggarakan oleh badan penyelenggara jaminan sosial ketenagakerjaan (BPJS). BPJS Kesehatan menyelenggarakan program kesehatan dan BPJS Ketenagakerjaan menyelenggarakan program jaminan kecelakaan kerja, jaminan hari tua, jaminan pensiun, dan jaminan kematian.Pekerja atau buruh wajib diikut sertakan kedalam program jaminan sosial tersebut.Kepesertaan program jaminan sosial tenaga kerja ini dilakukan secara wajib oleh perusahaan yang didaftarkan ke badan penyelenggara jaminan sosial ketenagakerjaan.

Setiap tahun berbeda produk yang merajai pasar internasional membuat permintaan produk yang beraneka ragam model dan bentuk, semakin sulit detail yang diminta pelanggan maka semakin mahal harga sebuah produk namun kualitas produk di perusahaan Alam bisa bersaing dipasaran. Semakin banyak permintaaan maka semakin riskan terjadi kecelakaan kerja karena tenaga kerja memiliki banyak orderan membuat mereka menjadi fokus pada produk dan melupakan keselamat kerja. Perlindungan diri sangat diperlukan dalam mengerjakan suatu produk mulai dari sarung tangan, sepatu, helm dan masker merupakan kebutuhan tenaga kerja saat mengerjakan produk, hal itu pula yang menjadi tuntutan bagi perusahaan agar selalu menyediakan alat keselamatan kerja yang dibutuhkan para pekerja demi menghasilkan suatu produk yang baik. Semakin banyak produk yang diinginkan membuat semakin tinggi tingkat kecelakaan kerja yang terjadi maka setiap pekerja harus saling mengingatkan satu sama lain dalam hal keselamatan kerja. Faktor kelelahan menjadi hal yang biasa terjadi pada perusahaan produktif menghasilkan produk dalam jumlah banyak. Kebijakan perusahaan sangat diperlukan saat situasi tenaga kerja sedang kelalahan maka harus diberi waktu beristirahat atau libur demi menunjang produktifitas para tenaga kerja yang lain.

UD. Alam memberlakukan iuran demi menjaga sistem kekeluargaan dapat terjaga antar karyawan dan tenaga kerja. Kegiatan rutin yang dilakukan setiap bulan dikenakan biaya sesuai kesepakatan para pekerja dan terdapat sanksi bagi pekerja yang telat membayar iuran. Dana yang didapat dari iuran akan dipergunakan untuk menunjang para pekerja sendiri seperti:

a. Biaya pengobatan bagi tenaga kerja yang tertimpa musibah seperti sakit berkelanjutan dan kecelakaan saat membuat suatu produk.

b. Biaya bagi karyawan yang mengalami musibah semisal ada keluarga pekerja yang mengalami sakit dan harus di operasi, namun membutuhkan biaya yang tidak sedikit.

c. Dana perbaikan alat kerja yang biasa dipergunakan para pekerja untuk membuat suatu produk.

Perusahaan Alam memang terkenal sebagai perusahaan yang senantiasa mensejahterakan para pekerjanya juga bersosial tinggi jika ada salah seorang anak perusahaannya mengalami musibah. Kesejahteraan tenaga kerja diutamakan disini mulai dari upah minimun sampai tunjangan yang didapat setiap bulan dan didaftarkan ke BPJS untuk meringankan biaya jika terjadi kecelakaan kerja ditambah iuran yang sangat berguna membantu pekerja yang memerlukan bantuan. Segala yang ada diperusahaan Alam sudah sesuai dengan peraturan pemerintah tentang ketenagakerjaan dimulai dari 
keselamatan kerja sampai tunjangan membuat para tenaga kerja menjadi produktif menghasilkan suatu produk.

Perusahaan Alam selain sebagai perusahaan yang mensejahterakan tenaga kerjanya juga sebagai panutan bagi perusahaan lain karena banyak perusahaan yang tidak mementingkan karyawan dan mementingkan kesuksesan diri sendiri dan perusahaannya saja. Pemerintah sebagai ujung tombak perekonomian sangat antusias melihat perkembangan perusahaan alam yang berdiri sudah hampir 10 tahun dan konsisten dengan putusannya mensejahterakan para pekerja. Jadi pelaksanaan jaminan kecelakaan kerja di UD. Alam belum dilaksanakan secara penuh atau optimal dengan alasan mengikutsertakan tenaga kerja kedalam program jaminan kecelakaan kerja akan menambah anggaran perusahaan dan terjadi permasalahan perekonomian pada perusahaan tersebut. Di sisi lain pihak pekerja tidak melakukan penuntutan haknya, karena kurangnya pengetahuan atau pemahaman mengenai Undang-undang dan Peraturan Pemerintah mengenai perlindungan tenaga kerja yang sebenarnya melindungi hak-hak mereka sebagai pekerja di UD. Alam. Jaminan tenaga kerja bertujuan untuk menanggulangi berbagai resiko yang mungkin terjadi seperti resiko kecelakaan kerja, sekaligus program jaminan sosial tenaga kerja ini dimaksud untuk memberikan kepastian berlangsungnya penerimaan penghasilan keluarga yang sebagian hilang, akibat dari terjadinya resiko-resiko kecelakaan kerja. Kecelakaan kerja yang menimpa pekerja karena hubungan kerja, perusahaan diwajibkan untuk memberikan santunan kepada pekerja yang tertimpa kecelakaan kerja.

\section{SIMPULAN DAN SARAN}

\section{Simpulan}

Bentuk-bentuk perlindungan hukum tanggung jawab UD. Alam yang telah diberikan terhadap pekerjanya berupa perlindungan ekonomis dimana pekerjanya diberikan upah minimum kabupaten/kota (UMK), perlindungan teknis dimana pekerjanya diberikan waktu penyesuaian terhadap alat- alat yang dipergunakan di perusahaan yang belum biasa digunakan, dan perlindungan sosial dimana pihak UD. Alam membiayai pengobatan dan memberikan santunan berupa uang tunai, apabila ada salah satu karyawannya yang mengalami kecelakaan kerja. Sampai saat ini UD. Alam belum mendaftarkan pekerjanya kedalam program jaminan kecelakaan kerja sehingga Pelaksanaan program jaminan kecelakaan kerja di UD. Alam Banjar Pendem Kabupaten Jembrana belum terlaksana secara efektif. Kemudian, faktor ekonomi menjadi kendala UD. Alam belum mendaftarkan pekerjanya kedalam program jaminan kecelakaan kerja, hal ini disebabkan oleh beratnya beban yang ditanggung pengusaha untuk membayar iuran jaminan kecelakaan kerja dan juga prosedur untuk pengajuan jaminan kecelakaan kerja selalu terhambat dengan syarat- syarat yang tidak lengkap sehingga membutuhkan waktu terlalu lama untuk mendaftarkan pekerjanya kedalam program jaminan kecelakaan kerja.

\section{Saran}

Berdasarkan kesimpulan tersebut diatas dalam rangka memperbaiki kondisi kerja di UD. Alam peneliti dapat memberikan saran bahwa dalam rangka menjamin efektivitas berlakunya perlindungan sosial kecelakaan kerja disarankan kepada Dinas Tenaga Kerja Kabupaten Jembrana untuk mengintensifkan pelaksanaan sosialisasi kepada pelaku usaha mengenai substansi jaminan kecelakaan kerja. Dalam rangka menjamin kepastian hukum hendaknya pelaku usaha segera mengikut sertakan tenaga kerjanya sebagai anggota program kecelakaan kerja yang diselenggarakan oleh Badan Penyelenggara Jaminan Sosial (BPJS).

\section{DAFTAR PUSTAKA}

Ahmad, B. (2008). Metode Penelitian Hukum. Bandung: Pustakasetia. Asyhadie, Z. (2008). Aspek-Aspek Hukum Jaminan Sosial Tenaga Kerja Di Indonesia. Jakarta: Rajawali Pers. Husni, L. (2016). Pengantar Hukum Ketenagakerjaan. Jakarta: PT. Raja Grafindo Persada.

Marzuki, P. M. (2011). Penelitian Hukum. Jakarta: Kencana Prenida Media.

Soekanto, S., \& Mamudji, S. (2003). Penelitian Hukum Normatif: Suatu Tinjauan Singkat. Jakarta: PT. RajaGrafindo Persada.

Waluyo, B. (2002). Penelitian Hukum Praktek. Jakarta: Sinar Grafika.

Wijayanti, A. (2009). Hukum Ketenagakerjaan Pasca Reformasi. Jakarta: Penerbit Sinar Grafika. 